\title{
Kondisi Suhu, Salinitas, pH dan Oksigen Terlarut di Perairan Terumbu Karang Ternate, Tidore dan Sekitarnya
}

\section{(Conditions of Temperature, Salinity, $\mathrm{pH}$ And Dissolved Oxygen in the reef waters of Ternate, Tidore and surrounding areas)}

\author{
Simon I. Patty ${ }^{1}$ dan Nebuchadnezzar Akbar ${ }^{2}$ \\ ${ }^{1}$ Loka Konservasi Biota Laut Bitung-LIPI \\ ${ }^{2}$ Program Studi Ilmu Kelautan, FPIK. Universitas Khairun, Ternate \\ E-mail : pattysimon@ymail.com
}

\begin{abstract}
ABSTRAK
Pengamatan suhu, salinitas, $\mathrm{pH}$ dan oksigen terlarut di perairan terumbu karang Ternate, Tidore dan sekitarnya, telah dilaksanakan pada bulan Juli 2018. Hasil analisis statistik dengan menggunakan uji-t menunjukkan bahwa suhu air dan oksigen terlarut di lapisan permukaan dengan dekat dasar adalah berbeda nyata. Salintas dan $\mathrm{pH}$ tidak berbeda nyata antara lapisan permukaan dengan dekat dasar. Variasi kedalaman air laut terhadap suhu, salinitas, $\mathrm{pH}$ dan kadar oksigen menunjukkan perbedaan yang relatip kecil namun masih dalam batas ambang kehidupan biota laut. Pada lapisan permukaan nilai AOU yang positip diperoleh 85,71\% dan AOU negatip 14,29\% menggambarkan adanya lokasi yang pemakaian oksigennya lebih besar daripada produksi oksigen. Nilai suhu air laut, salinitas, $\mathrm{pH}$ dan oksigen terlarut di perairan ternate, tidore dan sekitarnya belum menunjukkan dampak negatif terhadap lingkungan perairan dan masih baik untuk pertumbuhan terumbu karang.
\end{abstract}

Kata Kunci: Kualitas air, suhu, salinitas, pH, oksigen terlarut, terumbu karang.

\begin{abstract}
Observation of water temperature, salinity, $\mathrm{pH}$ and dissolved oxygen in coral reef of Ternate, Tidore and surrounding areas has been carried out in July 2018. The results of statistical analysis using the t-test indicate that the water temperature and dissolved oxygen in the surface layer and the bottom layer is significantly different, while Salinity and $p H$ weren't differ significantly between both layers. The correlation between sea water depth variations with temperature, salinity, $\mathrm{pH}$ and oxygen levels showed relatively small differences but were still within the threshold of marine biota life. On the surface layer, $85.71 \%$ positive AOU value were obtained and a negative AOU of $14.29 \%$, illustrates the presence of sites with higher oxygen consumption compared to oxygen production. The value of sea water temperature, salinity, $\mathrm{pH}$ and dissolved oxygen of coral reef areas in Ternate, Tidore and the surrounding areas has not shown negative impacts on the aquatic environment and is still adequate for coral reef growth.
\end{abstract}

Keywords: Water quality, temperature, salinity, $\mathrm{pH}$, dissolved oxygen, coral reefs. 


\section{Pendahuluan}

Perairan Ternate, Tidore dan sekitarnya terletak di laut Maluku merupakan bagian dari wilayah segitiga terumbu karang (coral triangle). Wilayah perairan ini memiliki produktivitas dan keanekaragaman hayati (biodiversity) laut yang relatif tinggi, sehingga menjadi sumber plasma nutfah bagi kehidupan biota laut. Tercatat terumbu karang (coral reefs) 144 jenis, lamun (seagrass) 9 jenis yang dihuni oleh berbagai biota flora dan fauna (Giyanto et al,2012). Terumbu karang merupakan tempat hidup dan berkembang biak bagi berbagai biota laut yang dijadikan sebagai tempat mencari makan (feeding ground), daerah asuhan (nursery ground), dan tempat memijah (spawning ground), disamping berperan sebagai penahan gelombang dan ombak terhadap pengikisan pantai (Fahrul, 2007). Pengambilan biota karang dengan cara-cara yang tidak ramah lingkungan telah mengakibatkan banyaknya terumbu karang yang mengalami kerusakan, selain itu faktor lain yang dapat menyebabkan rusaknya terumbu karang adalah kualitas perairan, seperti perubahan suhu, tingginya kandungan sedimen, kekeruhan dan sebagainya. Terumbu karang sangat sensitif terhadap pengaruh lingkungan, baik yang bersifat fisik (dinamika perairan laut dan pantai), kerusakan akibat aktivitas manusia, pencemaran bahan kimia maupun kerusakan akibat aktivitas biologis (Burke et al, 2002; Dahuri, 2003).

Suhu, salinitas, $\mathrm{pH}$ dan oksigen terlarut merupakan parameter yang sangat penting terhadap kehidupan terumbu karang. Hal ini karena berbagai aspek distribusi parameter seperti reaksi fisika, kimia dan proses biologi merupakan fungsi dari suhu, sehingga suhu ini menjadi suatu variabel yang menentukan. Secara geografi, suhu dapat membatasi sebaran karang. Sedangkan salinitas merupakan faktor penting bagi penyebaran organisme perairan laut, $\mathrm{pH}$ berpengaruh terhadap daya tahan organisme di mana pada $\mathrm{pH}$ yang rendah akan mengganggu penyerapan oksigen telarut oleh organisme tersebut (Boyd, 1979) dan oksigen dapat merupakan faktor pembatas dalam penentuan kehadiran makhluk hidup di dalam air. Perubahan suhu, rendahnya salinitas, $\mathrm{pH}$ dan menurunnya kadar oksigen terlarut pada kisaran tertentu dapat menyebabkan rusaknya terumbu karang dan akan mempengaruhi kehidupan organisme perairan, diantaranya kematian, menghambat proses pertumbuhan, mengganggu proses respirasi dan lainlain. Tujuan penelitian ini adalah untuk mendapatkan informasi dasar mengenai kondisi suhu, salinitas, $\mathrm{pH}$ dan oksigen terlarut pada area terumbu karang serta faktor-faktor yang mempengaruhiya di perairan Ternate, Tidore dan sekitarnya.

\section{Metode Penelitian}

\subsection{Waktu dan tempat penelitian}

Penelitian dilakukan di perairan terumbu karang Ternate, Tidore dan sekitarnya pada bulan Juli 2018. Penentuan posisi masing-masing stasiun penelitian dilakukan dengan menggunakan handportable GPS (Geographical Positioning System) (Gambar 1)

\subsection{Pengambilan data perairan}

Parameter hidrologi yang diamati adalah suhu, salinitas, $\mathrm{pH}$ dan oksigen terlarut. Sampel air laut diambil menggunakan tabung nansen sebanyak 14 stasiun pada lapisan permukaan dan dekat dasar. 


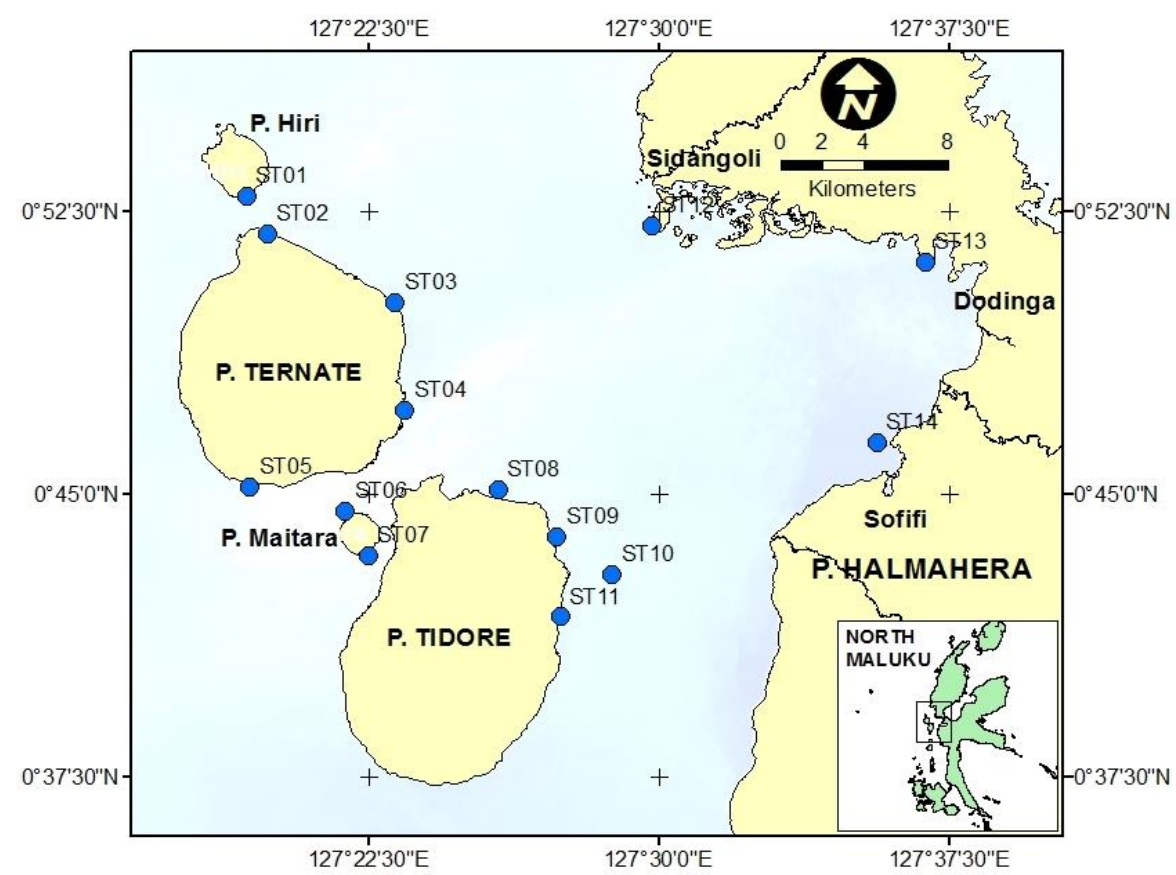

Gambar 1. Stasiun penelitian (titik biru = lokasi pengambilan data)

Pengukuran beberapa parameter hidrologi dilakukan secara in situ (langsung di lapangan). Suhu air laut diukur dengan menggunakan thermometer GMK-910T, nilai suhunya dinyatakan dalam derajat Celsius $\left({ }^{\circ} \mathrm{C}\right)$. Salinitas diamati dengan menggunakan Atago hand refractometer, nilainya dinyatakan dalam per mil $(\%)$. pH air laut diukur dengan menggunakan pH meter AZ 8682. Kadar oksigen terlarut ditentukan dengan cara metoda elektrokimia menggunakan alat DO meter AZ 8563 dan nilainya dinyatakan dalam mg/l. Perhitungan nilai Apparent Oxygen Utilization (AOU) berdasarkan pendekatan empiris Alekin (dalam Sapulete \& Birowo, 1990). Analisa statistik (uji-t) dengan menggunakan SPSS 16.

\section{Hasil dan Pembahasan}

Hasil pengamatan kualitas air yang meliputi suhu, salinitas, $\mathrm{pH}$ dan oksigen terlarut di perairan terumbu karang Ternate, Tidore dan sekitarnya (Tabel 1). Hasil analisa uji-t untuk mengetahui ada tidaknya perbedaan antara kondisi perairan di lapisan permukaan dan dekat dasar (Tabel 2).

Tabel 1. Hasil statistik deskriptif suhu, salinitas, $\mathrm{pH}$ dan oksigen terlarut di perairan Ternate, Tidore dan sekitarnya dan sekitarnya.

\begin{tabular}{lcccc|cccc}
\hline \multirow{4}{*}{ Kosentrasi } & \multicolumn{4}{c|}{ Permukaan $(0 \mathrm{~m})$} & \multicolumn{3}{c}{ Dekat Dasar $(5-15 \mathrm{~m})$} \\
\cline { 2 - 9 } & $\begin{array}{c}\text { Suhu } \\
\left({ }^{\circ} \mathrm{C}\right)\end{array}$ & $\begin{array}{c}\text { Sal } \\
(\% / \mathrm{oo})\end{array}$ & $\mathrm{pH}$ & $\begin{array}{c}\mathrm{DO} \\
(\mathrm{mg} / \mathrm{l})\end{array}$ & $\begin{array}{c}\text { Suhu } \\
\left({ }^{\circ} \mathrm{C}\right)\end{array}$ & $\begin{array}{c}\text { Sal } \\
\left(\% \%_{\mathrm{oo}}\right)\end{array}$ & $\mathrm{pH}$ & $\begin{array}{c}\mathrm{DO} \\
(\mathrm{mg} / \mathrm{l})\end{array}$ \\
\hline Minimum & 29,4 & 30 & 7,89 & 4,09 & 29,2 & 30,5 & 8,08 & 4,06 \\
Maksimum & 30,4 & 33 & 8,32 & 6,44 & 30,1 & 34 & 8,28 & 6,36 \\
Rata-rata & 29,9 & 31,4 & 8,13 & 6,02 & 29,6 & 31,9 & 8,17 & 5,9 \\
Stand. Deviasi & 0,29 & 0,72 & 0,11 & 0,66 & 0,31 & 0,84 & 0,06 & 0,62 \\
Koef. Variasi & 0,96 & 2,29 & 1,39 & 10,96 & 1,05 & 2,62 & 0,74 & 10,48 \\
\hline
\end{tabular}


ISSN 2620-570X

JuRnal Ilmu Kelautan KePUlauan, 1 (2) ; 1-10, DeSEMBER 2018

Tabel 2. Analisis uji-t terhadap suhu, salinitas, $\mathrm{pH}$ dan oksigen terlarut.

\begin{tabular}{lccccc}
\hline \multirow{2}{*}{ Parameter } & \multirow{2}{*}{ Sig. (2-tailed) } & \multirow{2}{*}{ t-hit } & df & \multicolumn{2}{c}{ t-tab } \\
\cline { 5 - 6 } & & & & $5 \%$ & $1 \%$ \\
\hline Suhu permukaan-dekat dasar & 0 & $5,062^{* *}$ & 13 & 2,16 & 3,01 \\
Salinitas permukaan-dekat dasar & 0 & 1,594 & 13 & 2,16 & 3,01 \\
pH permukaan-dekat dasar & 0,135 & 13 & 2,16 & 3,01 \\
Oksigen permukaan-dekat dasar & 0 & $4,695^{*}$ & 13 & 2,16 & 3,01 \\
\hline Keterangan: * berbeda nyata, ** berbeda sangat nyata & & & & &
\end{tabular}

\section{Suhu}

Suhu air lapisan permukaan dan dekat yang diperoleh di perairan ini menunjukkan perbedaan yang signifikan. Suhu air lapisan permukaan berkisar antara $29,4-30,4{ }^{\circ} \mathrm{C}$ dengan nilai rata-rata $29,9 \pm 0,29{ }^{\circ} \mathrm{C}$, sedangkan suhu air di dekat dasar berkisar antara 29,2-30,1 ${ }^{\circ} \mathrm{C}$ dengan nilai rata-rata $29,6 \pm 0,31{ }^{\circ} \mathrm{C}$ (Gambar 2). Keadaan suhu di daerah ini masih tergolong wajar untuk perairan tropik. Variasi suhu perairan tropik tergolong wajar apabila nilainya berkisar antara 25,6-32,3 ${ }^{\circ} \mathrm{C}$ (Ilahude dan Liasaputra, 1980).

Dari data di atas menunjukkan bahwa rata-rata suhu air permurkaan lebih tinggi dari dekat dasar. Kondisi ini disebabkan karena penetrasi cahaya matahari makin berkurang dengan bertambahnya kedalaman atau semakin mendekati dasar. Fenomena ini diperkuat oleh hasil analisis statistik dengan menggunakan uji-t yang menunjukkan bahwa terdapat perbedaan sangat nyata (t-hit > t-tab) antara suhu air di lapisan permukaan dengan suhu air di dekat dasar (Tabel 2). Suhu air laut lapisan permukaan maupun dekat dasar dengan kadar terendah dijumpai di stasion ST11, sedangkan suhu tertinggi dijumpai di stasiun ST13 (Gambar 2). Bervariasinya nilai suhu air yang terjadi, mengindikasikan bahwa nilai suhu di perairan ini dipengruhi oleh fakktor eksternal antara lain cuaca dan angin. Laporan Officer (1976) mengemukakan bahwa kondisi suhu air di suatu perairan di pengaruhi terutama oleh kondisi atmosfir, cuaca dan intensitas matahari yang masuk ke laut. Selain itu sebaran suhu air juga dipengaruhi oleh faktor geografis dan dinamika arus (Pond dan Pickard,1978).

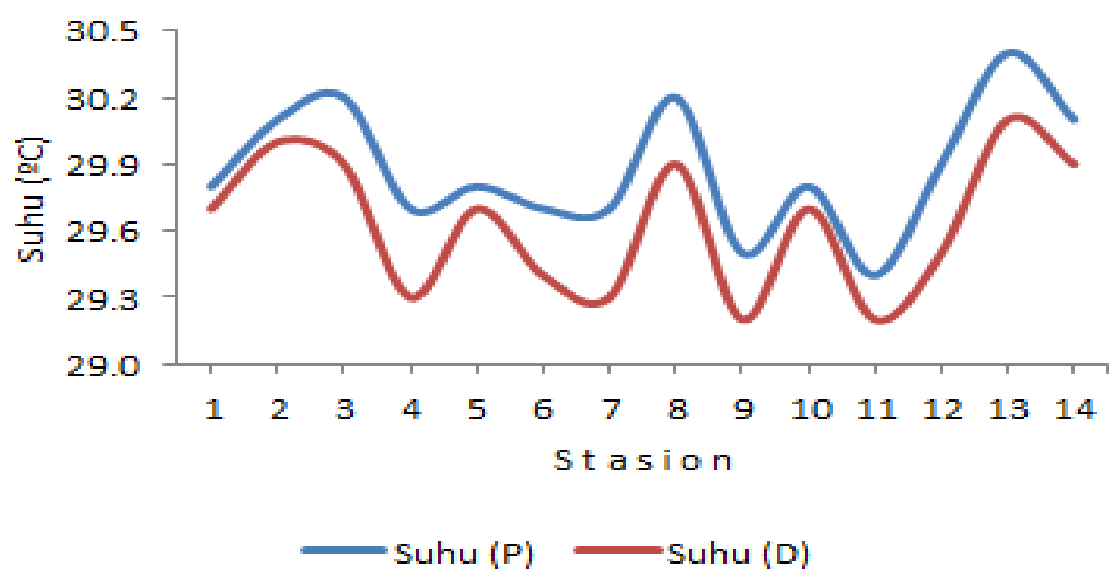

Gambar 2. Suhu air laut permukaan (P) dan dekat dasar (D) di perairan

Ternate, Tidore dan sekitarnya. 
Secara keseluruhan suhu air di perairan ini berkisar antara $29,2-30,4{ }^{\circ} \mathrm{C}$, dengan nilai rata-rata $29,8 \pm 0,32{ }^{\circ} \mathrm{C}$. Suhu ini sesuai dengan kisaran suhu yang umum dijumpai di perairan laut Indonesia berkisar antara 27-32 ${ }^{\circ} \mathrm{C}$ (Nybakken, 1988). Parameter suhu air laut mempunyai toleransi terhadap pertumbuhan karang batu, suhu optimum untuk terumbu karang $25-30{ }^{\circ} \mathrm{C}$. Sukarno et al (1981) yang menyatakan bahwa karang batu pembentuk terumbu karang memerlukan suhu air laut yang agak tinggi yaitu diatas $20-30{ }^{\circ} \mathrm{C}$. Untuk pertumbuhan dan perkembangan terumbu karang, suhu yang ideal berkisar antara $25-28{ }^{\circ} \mathrm{C}$ dan antara $23-29{ }^{\circ} \mathrm{C}$ (Eliza, 1992). Suhu ini juga masih sesuai untuk kehidupan biota laut (ikan dan sebagainya), suhu untuk biota laut adalah berkisar antara $28-32{ }^{\circ} \mathrm{C}$ dan diperbolehkan terjadi perubahan sampai dengan $<2{ }^{\circ} \mathrm{C}$ dari suhu alami (KLH, 2004). Sejauh ini, kisaran suhu yang teramati masih dalam batas kisaran optimal suhu air laut yaitu $28-32{ }^{\circ} \mathrm{C}$.

\section{Salinitas}

Nilai salinitas wilayah laut Indonesia umumnya berkisar antara 28-33\% (Nontji, 2002). Hasil pengamatan menunjukkan bahwa salinitas lapisan permukaan berkisar antara 30,0-33,0\% dengan nilai rata-rata $31,4 \pm 0,72 \%$, sedangkan salinitas di dekat dasar berkisar antara 30,5-34,0

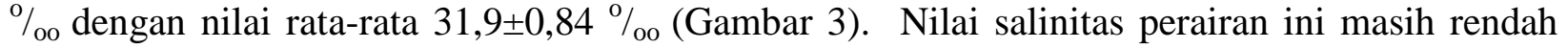
dibawah batasan salinitas yang normal air pantai dan air campuran yaitu berkisar antara 32,0$34,0 \%$ (Romimohtarto dan Thayib,1982). Rendahnya nilai salinitas di perairan ini menunjukkan adanya pengaruh dari daratan seperti percampuran dengan air tawar yang terbawa aliran sungai. Sebagaimana Nontji (2002) mengungkapkan bahwa tinggi rendahnya nilai salinitas di laut dipengaruhi oleh berbagai faktor, seperti pola sirkulasi air, penguapan, curah hujan dan aliran sungai. Ditegaskan Banjarnahor (2000), bahwa perbedaan nilai salinitas air laut dapat disebabkan oleh terjadinya pengacauan (mixing) akibat gelombang laut ataupun gerakan massa air yang ditimbulkan oleh tiupan angin.

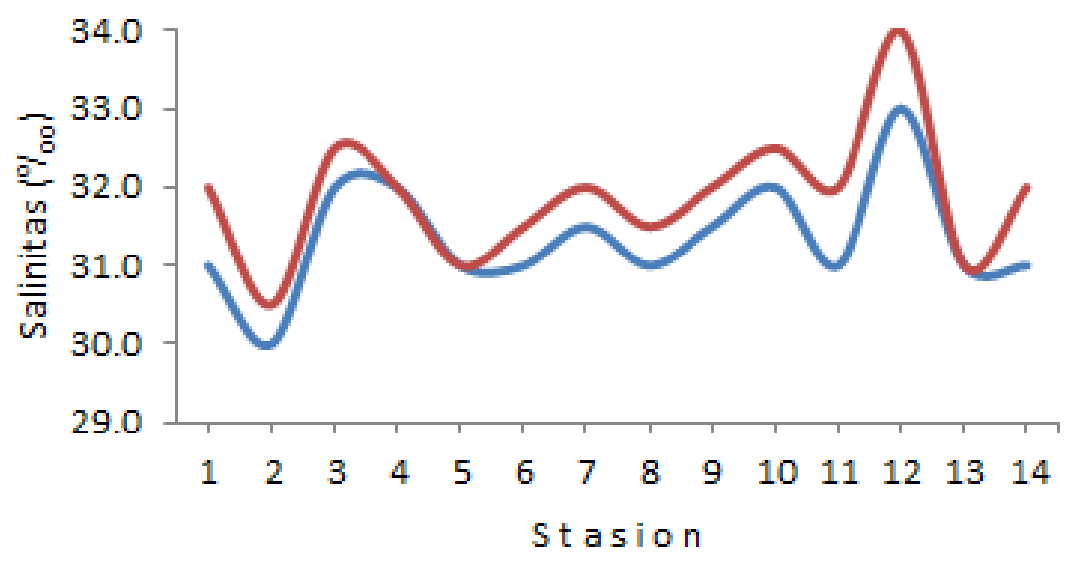

Salinitas (P) Salinitas (D)

Gambar 3. Salinitas permukaan (P) dan dekat dasar (D) di perairan Ternate, Tidore dan sekitarnya.

Hasil analisis statistik dengan menggunakan uji-t menunjukkan bahwa terdapat perbedaan antara salinitas di lapisan permukaan dengan salinitas di lapisan dekat dasar (t-hit > ttab). Salinitas lapisan permukaan maupun dekat dasar terendah dijumpai di stasion ST02, 
sedangkan salinitas tertinggi dijumpai di stasion ST12 (Gambar 3). Salinitas yang diperoleh di perairan ini masih baik untuk pertumbuhan dan perkembangan karang. Karang batu dapat hidup dalam batas salinitas tertentu yaitu antara 25-40 \% (Smith dalam Sukarno et al, 1981). Menurut Eliza (1992), bahwa salinitas yang ideal untuk pertumbuhan dan perkembangan karang juga berkisar antara 25-40 \%. Demikian pula Nontji dalam Sudiarta (1995) menyatakan bahwa hewan karang mempunyai toleransi salinitas berkisar 27-40 \% baik untuk kehidupan organisme laut lainnya. KLH, 2004 menetapkan salinitas sebesar 33-34 \%o salinitas alami untuk terumbu karang dan diperbolehkan terjadi perubahan sampai dengan $<5 \%$ salinitas rata-rata musiman.

\section{Derajat keasaman (pH)}

Variasi nilai derajat keasaman $(\mathrm{pH})$ air laut dapat dijadikan sebagai salah satu identifikasi kualitas air laut. Pada kisaran nilai $\mathrm{pH}$ tertentu dapat diindikasikan terjadinya suatu perubahan dalam kualitas perairan. Hasil pengukuran menunjukkan bahwa $\mathrm{pH}$ air laut permukaan berkisar

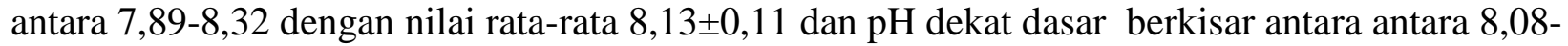
8,28 dengan nilai rata-rata 8,17 $\pm 0,06$ (Gambar 4). Kisaran ini sesuai dengan nila $\mathrm{pH}$ suatu perairan normal. Menurut Salm (1984), pH di suatu perairan yang normal berkisar antara 8,0-8,3. Secara umum tidak ada perbedaan yang nyata antara $\mathrm{pH}$ di lapisan permukaan dengan $\mathrm{pH}$ di dekat dasar (t-hit < t-tab). Dari Gambar 4, terlihat $\mathrm{pH}$ air laut lapisan permukaan maupun dekat dasar terendah dijumpai di stasion ST05 dan nilai pH tertinggi dijumpai di stasion ST08. Rendahnya nilai $\mathrm{pH}$ di perairan ini menunjukkan adanya pengaruh massa air dari beberapa muara sungai disekitarnya. Nilai $\mathrm{pH}$ dalam suatu perairan dipengaruhi oleh berbagai faktor diantaranya curah hujan dan pengaruh dari daratan maupun proses oksidasi yang dapat mengakibatkan rendahnya nilai pH (Edward dan Tarigan, 2003).

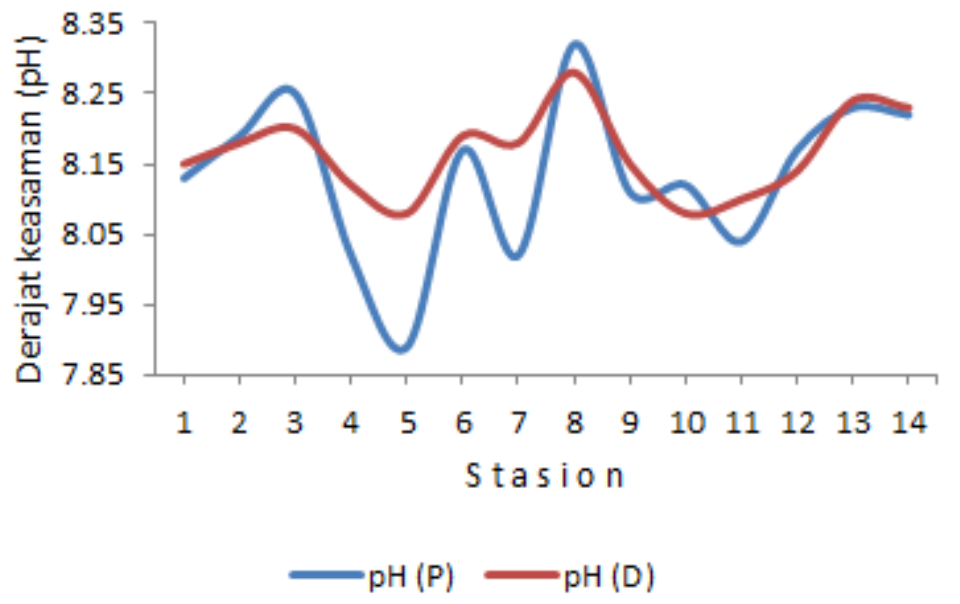

Gambar 4. Derajat keasaman/pH permukaan (P) dan dekat dasar (D) di perairan Ternate, Tidore dan sekitarnya.

Umumnya air laut relatif lebih alkali (basa) sekitar 8.0 akan tetapi organisme air laut relatif mampu beradaptasi dengan ruang $\mathrm{pH}$ yang lebar (Udi at. al, 2011). Bila dilihat dari standar baku mutu, maka nilai $\mathrm{pH}$ yang diperoleh tidak melebihi standar baku mutu yang ditetapkan menurut Keputusan Menteri Lingkungan Hidup, (2004) yaitu 7,0 - 8,5. Perairan dengan kisaran $\mathrm{pH}$ antara 7 - 8,5 merupakan daerah yang potensial sebagai tempat budidaya dan rekreasi, sedangkan untuk kepentingan terumbu karang nilai $\mathrm{pH}$ berkisar antara 6-9 (Edward dan 
Tarigan, 2003). Pescod dalam Susana (2005) memberikan batasan $\mathrm{pH}$ yang ideal bagi biota laut nilainya berkisar antara 6,5 - 8,5; sedangkan EPA, 1973 menetapkan kisaran pH 6,5 - 8,5 untuk perikanan. Dengan demikian besarnya nilai $\mathrm{pH}$ air laut di perairan ini masih dalam batas aman dan memungkinkan biota laut untuk bertahan hidup.

\section{Oksigen terlarut (DO)}

Kadar oksigen terlarut di dalam massa air nilainya adalah relatif, biasanya berkisar antara 6 - 14 mg/l (W.D. Connel, G.J. Miller, 1995). Kadar oksigen terlarut lapisan permukaan di perairan ini berkisar antara 4,09 - 6,44 mg/l, dengan nilai rata-rata 6,02 $\pm 0,66 \mathrm{mg} / \mathrm{l}$ dan dekat

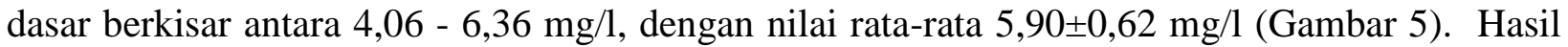
analisis statistik dengan menggunakan uji-t menunjukkan bahwa terdapat perbedaan antara kadar oksigen terlarut di lapisan permukaan dengan oksigen terlarut di lapisan dekat dasar (t-hit > ttab). Kosentrasi oksigen terlarut lapisan permukaan maupun dekat dasar dengan kadar terendah dijumpai di stasiun ST05, sedangkan kadar oksigen terlarut teringgi terdapat di stasiun ST10 dan stasiun ST08 (Gambar 5). Kadar oksigen terlarut di lapisan permukaan laut umumnya, yaitu berkisar antara 5,7 - 8,5 mg/l (Sutamihardja, 1987). Rendahnya kadar oksigen di perairan ini erat kaitannya dengan tingginya kekeruhan dan juga mungkin disebabkan oleh semakin meningkatnya aktivitas mikro organisme dalam menguraikan zat organik menjadi zat anorganik yang menggunakan oksigen terlarut.

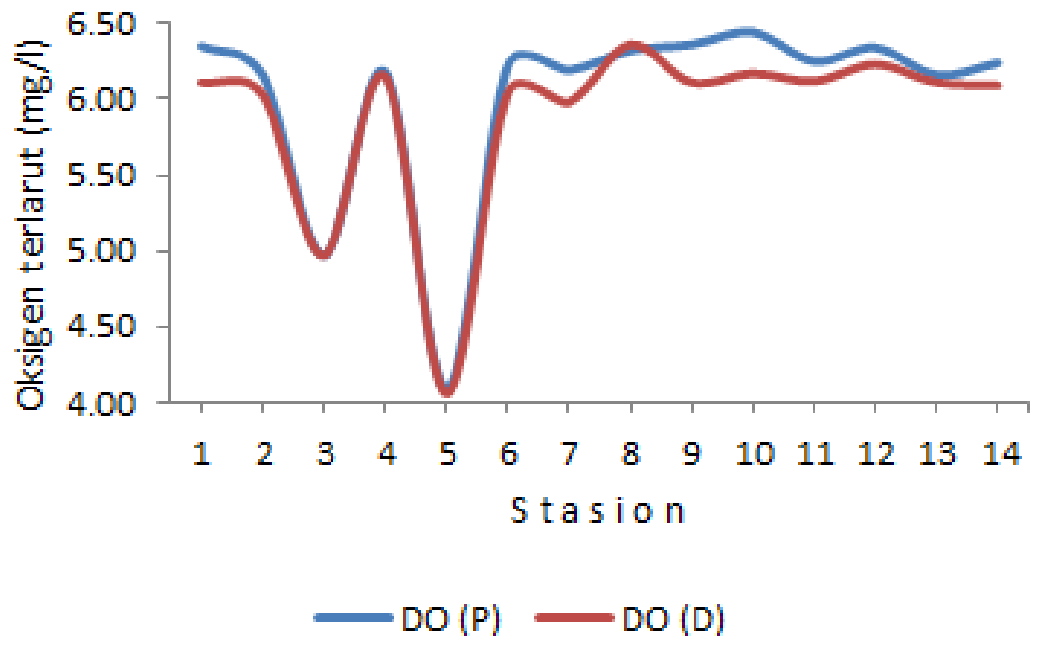

Gambar 5. Oksigen terlarut permukaan (P) dan dekat dasar (D) di perairan Ternate, Tidore dan sekitarnya.

Secara keseluruhan kadar oksigen terlarut di perairan ini berkisar antara 4,06 - 6,44 mg/l, dengan nilai rata-rata 5,96 $\pm 0,63 \mathrm{mg} / \mathrm{l}$. Nilai ini masih sesuai dengan baku mutu air laut untuk biota laut yaitu $\geq 5 \mathrm{mg} / \mathrm{l}$ ( KLH (2004), namun masih dalam kategori tercemar ringan yaitu 4,5 6,4 mg/l (Lee at. al., 1978). Menurut Da'i (1991), kadar oksigen di Teluk Nanwan, Taiwan dimana terumbu karang tumbuh dan berkembang dengan baik berkisar antara 4,27-7,14 mg/l. Rivai,1983 mengatakan bahwa pada umumnya kandungan oksigen sebesar $5 \mathrm{mg} / \mathrm{l}$ dengan suhu air berkisar antara 20-30 ${ }^{\circ} \mathrm{C}$ relatif masih baik untuk kehidupan ikan-ikan, bahkan apabila dalam perairan tidak terdapat senyawa-senyawa yang bersifat toksik (tidak tercemar) kandungan oksigen sebesar $2 \mathrm{mg} / \mathrm{l}$ sudah cukup untuk mendukung kehidupan organisme perairan. Kadar oksigen di perairan laut yang tercemar ringan di lapisan permukaan adalah $5 \mathrm{mg} / \mathrm{l}$ (Sutamihardja, 
1987). Jika dilihat dari kadar oksigen terlarutnya dapat dikatakan bahwa perairan ini relatif belum tercemar oleh senyawa-senyawa organis dan masih baik untuk kehidupan biota laut.

Tabel 3. Kisaran dan rata-rata oksigen terlarut dan nilai AOU di perairan Ternate, Tidore dan sekitarnya dan sekitarnya.

\begin{tabular}{lcccc}
\hline \multirow{2}{*}{ Kedalaman } & \multicolumn{2}{c}{ Oksigen terlarut $(\mathrm{mg} / \mathrm{l})$} & \multicolumn{2}{c}{ AOU $(\mathrm{mg} / \mathrm{l})$} \\
\cline { 2 - 5 } & Kisaran & Rata-rata & Kisaran & Rata-rata \\
\hline Permukaan $(0 \mathrm{~m})$ & $4,09-6,44$ & 6,02 & $(-1,68)-0,71$ & 0,72 \\
Dekat dasar $(5-15 \mathrm{~m})$ & $4,06-6,36$ & 5,9 & $(-1,72)-0,62$ & 0,14 \\
\hline
\end{tabular}

Berdasarkan hasil perhitungan nilai Apparent Oxygen Utilization (AOU) yang merupakan perkiraan kasar tentang pemakaian oksigen oleh aktivitas biologi dan oksidasi zat-zat organik oleh mikroorganisme, diperoleh nilai AOU di lapisan permukaan berkisar antara $(-1,68)-0,71$ $\mathrm{mg} / \mathrm{l}$ dan dekat dasar berkisar antara $(-1,72)-0,62 \mathrm{mg} / \mathrm{l}$ (Tabel 3). Nilai AOU yang tertinggi $(0,71$ $\mathrm{mg} / \mathrm{l})$ ditemukan pada lokasi yang kadar oksigen terlarutnya tertinggi $(6,44 \mathrm{mg} / \mathrm{l})$ yaitu di stasiun ST10, sedangkan nilai AOU terendah $(-1,72 \mathrm{mg} / \mathrm{l})$ ditemukan pada lokasi yang kadar oksigen terlarutnya terendah $(4,06 \mathrm{mg} / \mathrm{l})$ yaitu di ST05. Hal ini menunjukkan bahwa di Stasiun ST10, jumlah oksigen terlarut untuk keperluan respirasi dan aktivitas mikroorganisme cukup banyak, sedangkan di Stasiun ST05 terjadi hal sebaliknya.

Dari 14 stasiun pengamatan pada lapisan permukaan terdapat 12 stasiun $(85,71 \%)$ yang mempunyai nilai AOU positip dan 2 stasiun yang nilainya negatip (14,29 \%). Ini berarti di perairan terumbu karang Ternate, Tidore dan sekitarnya ada 2 stasiun permukaan yang kebutuhan oksigennya lebih besar daripada produksi oksigen yaitu produksi $\mathrm{O}_{2}$ berasal dari udara dan proses fotosintetis. Tidak lancarnya proses fotosintesa dapat juga terjadi pada lapisan permukaan yang keruh dan pada lapisan yang lebih dalam dari daya tembus matahari serta pada malam hari (Simanjuntak, 2007).

\section{Kesimpulan}

Hasil pengamatan menunjukkan bahwa variasi nilai suhu, salinitas, $\mathrm{pH}$ dan oksigen terlarut di perairan Ternate, Tidore dan sekitarnya masih dalam kondisi relatif normal untuk kategori perairan pantai dan masih baik untuk kehidupan biota laut (KLH, 2004). Agar tidak terjadi perubahan kualitas perairan ke arah yang tidak kita inginkan, maka diharapkan dapat dilakukan penelitian yang berkesinambungan di perairan ini.

\section{Daftar Pustaka}

Banjarnahor, J. 2000. Atlas Ekosistem Pesisir Tanah Grogot, Kalimantan Timur. Puslitbang Oseanologi- LIPI Jakarta. 17 halaman

Boyd, C E. 1979. Water Quality in WarmWater Fish Pound Fish Culture. Agriculture Experiment Station. Auburn University. Auburn.

Burke, L E, Selig, Spalding M. 2002. Reefs at Risk in Southeast Asia. World Resources Intitute. USA.

Connel, W D dan Miller G J.1995. Kimia dan Ekotoksikologi Pencemaran. Terjemahan, Penerbit Universitas Indonesia. 520 halaman 
Dahuri, R. 2003. Keanekaragaman Hayati Laut Aset Pembangunan Berkelanjutan Indonesia, PT. Gramedia Pustaka Utama, Jakarta.

Dai, CF.1991. Reef Environment and Coral Fauna of Southern Taiwan. Atoll Resources Bulletin 354:1.

Edward dan Tarigan Z.2003. Pemantauan kondisi hidrologi diperairan Raha P. Muna, Sulawesi Tenggara Dalam Kaitannya Dengan Kondisi Terumbu Karang. Makara, Sains, Vol. 7 (2): 73-82.

Eliza, 1992. Dampak Pariwisata terhadap pertumbuhan terumbu karang. Lingkungan dan Pembangunan, 12(3): 150-170.

Fahrul, M F. 2007. Metode Sampling Bioekologi. Bumi Aksara. Jakarta.

Giyanto, R, Manogar, Siringoringo, Budiyanto A, Wahidin N. 2010. Kondisi Terumbu Karang dan Struktur Komunitas Karang Batu di Perairan Ternate, Tidore dan Sekitarnya. Ekosistem Ternate, Tidore dan Sekitarnya, Propinsi Maluku Utara, P2O-LIPI Jakarta, hal 20-39.

Ilahude, A G, Liasaputra. 1980. Sebaran Normal Parameter Hidrologi di Teluk Jakarta. Dalam : Teluk Jakarta. Penyajian fisika, kimia, biologi dan geologi (A. Nontji, A. Djamali, eds.). LON-LIPI: 1-40.

Lee, C D. Wang S B, Kuo C L. 1978. Benthic Macro Invertebrate and Fish as Biological Indicator of Water Quality, With Reference to Community Diversity Index In Onano, E. A. R., B.N. Lohani and Thanh. Water Pollution Control in Developing Countries. The Asian Institute of Technology, Bangkok.

Kementerian Lingkungan Hidup. 2004. Keputusan Menteri Negara Lingkungan Hidup No.51 Tahun 2004 Tentang Baku Mutu Air Laut Untuk Biota Laut. Jakarta, hal. 32.

Nontji, A. 2002. Laut Nusantara. Penerbit Djambatan. Jakarta: 59-67.

Nybakken, WJ.1988. Biologi Laut. Suatu Pendekatan Ekologis. Gramedia, Jakarta: 459 hal.

Officer, CB. 1976. Physical Oseanography of Estuaries and Associated Coastal Waters.John Willey and Sons. New York: 465 pp.

Pond dan Pickard. 1978. Introductory Dynamical Oceanography. Pergamon Press. Pub. Hedington Hill Hall, Oxford: 486 pp.

Riva'i, RS, Pertagunawan, K.1983. Biologi Perikanan I, Penerbit CV. Kayago, Jakarta, 143 hal.

Romimohtarto, K dan Thayib, S.S., 1982. Kondisi Lingkungan dan Laut di Indonesia, LONLIPI, Jakarta: 246 hal.

Salm, R V.1984. Coral Reef Management Handbook, Unesco-Rostrea, Jakarta, p. 15.

Sapulete, D dan Birowo S.1989. Kandungan oksigen di Teluk Ambon. Dalam: "Perairan Maluku dan sekitarnya”. (D. P. Praseno, W. S. Atmaja, I. Supangat, Ruyitno dan B. S. Sudibjo, eds). Balitbang Sumberdaya Laut P3O-LIPI, Ambon : 199 - 204.

Simanjuntak, M 2007. Oksigen terlarut dan Apparent Oxygen Utilization di Perairan Teluk Klabat, Pulau Bangka. Jour. Mar. Sci. Ilmu Kelautan. Univ. Diponegoro 12(2):59-66

Sudiarta, I K. 1995. Struktur Komunitas Biota Ekosistem Terumbu Karang dan Pemintakatan Kawasan Wisata Bahari Pulau Lembongan, Bali. Program Pasca Sarjana lnstitut Pertanian Bogor. 215 hal.

Sukarno, M , Hutomo M, Moosa M K, Darsono P. 1981. Temmbu Karang di Indonesia. Sumberdaya, Permasalahan dan Pengelolaannya. Proyek Penelitian Potensi Sumberdaya Alam di Indonesia. Lembaga Oseanologi Nasional. LIPI, Jakarta. 112 hal.

Susana, T. 2005. Kualitas Zat Hara Perairan Teluk Lada, Banten. Oseanologi dan Limnologi di Indonesia: 59 - 67. 
Sutamiharja, R T M. 1987. Kualitas dan Pencemaran Lingkungan. Fakultas Pascasarjana, Institut Pertanian Bogor: 92 hal.

Udi, Putra, Nana, S S. 2011. Manajemen Kualitas Air Pada Kegiatan Perikanan Budidaya. Departemen Kelautan dan Perikanan Direktorat Jendral Perikanan Budidaya Balai Budidaya Air Payau Takalar.

US Environmental Protection Agency (U.S. EPA, 1973). Water Quality Criteria 1972, EPA-R373-033-March 1973. p.177. 